\title{
The effect of job stress and need deficiency on performance
}

\author{
Nasir Ali $^{\mathrm{a}^{*}}$ and Mohammad Saleh Miralama
}

${ }^{a}$ Associate Professor, Department of Business Administration, College of Business, University of Jeddah, Saudi Arabia

\begin{tabular}{l}
\hline C H R O N I C L E \\
\hline Article history: \\
Received: February 3, 2019 \\
Received in revised format: March \\
10, 2019 \\
Accepted: March 14, 2019 \\
Available online: \\
March 14, 2019 \\
\hline Keywords: \\
Job Stress \\
Need Deficiency \\
Performance
\end{tabular}

\section{Introduction}

People in the present era are experiencing stress because all round changes took place in the globe have definitely reeled every one of us under stress. The last few decades of twentieth century witnessed wide spread technological development, innovations, speedy industrialization, fast social mobility, increased social expectancies, over demanding work environment and changing work values are coming so fast, leaving new challenges before us. Beehr and Newman (1978) viewed occupational stress as "a condition arising from the interaction of people and their jobs and characterized by changes within people that force them to deviate from their normal functioning". Schuler (1980) states that "stress is a dynamic condition in which an individual is confronted with an opportunity, constrain or demand to what he or she desired and for which the outcome is perceived to be both uncertain and important". It is noticed by various
A series of big changes have recently taken place in banking and financial sector as a result of global economic crisis, deregulated markets, globalization of economy and demonetization affecting the working lives of bank employees. The present exploration was planned to probe the associto find out the predictors of performance within the facets of job stress and need deficiencies among ees, consisting of 135 managerial and 180 non-managerial staff who were randomly selected from different branches of bank located in small cities in Uttar Pradesh, India. Job stress, need deficiency and performance measure scales were used to collect the information. Data were analyzed by stepwise multiple regressions analysis. The results observed as: i) total job stress, intrinsic impoverishment, role overload and unreasonable pressure showed significant positive correlation with performance and intrinsic impoverishment as well as role overload appeared as predictors of performance for sample group whereas esteem need, autonomy need were emerged as predictors and showed negative correlations with performance of employees; ii) esteem need, intrinsic impoverishment, strenuous working conditions and poor-peer relations were emerged as predictors of performance among managerial staff and iii) intrinsic impoverishment, role overload and strenuous working conditions appeared as predictors of performance for non-managerial staff. Further results discussed in details with suitable evidences. ations involving job stress, need deficiency and performance of bank employees. Further it aimed 
scholastic scholars, who considered stress as one of the foremost features in work organization which lead to decline in the performance (Agarwala et al., 1979; Ali, et al., 2004; Allam, 2007; Ali \& Allam, 2016; Allam, 2017a).

There are minuscule disparities in the fact of job anxiety, job stress, occupational stress, organizational stress, role stress and work stress but different researchers used the terms interchangeably in different studies (Al Kahtani et al., 2016; Allam, 2017b; Ali, 2017). However, organizational climate and structure are the reasons for organizational stress. Though, job stress is the result of mismatch with the abilities of individual required to accomplish the task, while work stress is adept amidst the occupational performance of the employees. In contrast, occupational stress is mainly described in an ampler manner, which alludes to the inseparable facets of job, organizational climate and structure as well as the role aspects in the firm. In this investigation, job stressors have been used as metonym to the occupational stress. A review of literature on the issue of occupational stress discloses that there are plenty of attributes related to the job, affect the behavior of workers and as a matter of facts usual life is upset (Brief et al., 1981; Allam \& Ali, 2007; Allam, 2013). Indeed, numerous theories pertaining to human stress and performance are supported by keeping in mind the sensible opinion that behavior is a function of physiognomy of the environment and person (Pervin, 1968; French et al., 1978; McGrath, 1976). It reflects that the foremost foundations of stress which can be classified predominantly as: factors intrinsic to job, organizational structure and climate, career development relationships at work, role in the organization and emotional exhaustion are unable to manage work life balance (Cooper \& Marshall, 1976; Allam \& Harish, 2010; Allam, 2019). The term human motivation started from the very beginning as the origin of human being on the surface of the earth and it has been considered as a very complex phenomenon. It might hardly be understood by simple observation. Indeed, there is a complexity in understanding the human need deficiency; researchers have most of the time concerned with the phenomenon because need deficiency gives rise to human behavior. In industrial and organizational context, most of the time human behavior has been considered as productive, related to result, outcome and efficiency or performance. At workplace human efficiency has been considered as one of the important and vital element of all resources for discharging responsibilities assigned with job incumbents. Taylor showed concern in employees' efficiency at work. He was basically concerned with minimizing cost, motivating employees and enhancing productivity and performance.

Generally, need deficiency motivates human beings towards felt needs: (i) to gratify physiological needs by achieving a goal; (ii) to gratify security needs; (iii) to satisfy social needs and avoid unpleasant experience; (iv) to achieve self- esteem and (v) to satisfy self-actualized needs (Maslow, 1943). The human being has a multiple of needs that must be gratified if he/she wants to enjoy his/her day-to-day living. $\mathrm{He} / \mathrm{sh}$ needs to respect, to lead, dominate, to admire, to follow, to emulate, and to be independent. Halloran (1978) contended that "motivation is an internal need satisfied by external expression" whereas job motivation is referred to as the intensity of behavior of employees in the work situation as they attempt to satisfy their particular need structure through the work they are doing. Thus, job motivation to be determined by need structure of employees; felt prospect to gratify needs in work atmosphere and perceived opportunity to gratify needs outside the work situation. The terms employee performance, individual performance or job performance have been used interchangeably by different people in various studies. There are different definitions given by different people but there is no consensus on a single definition. There is no straightforward concept of employee performance though it is the outcome of employees work related behavior at workplace. Schermerhorn (1989) stated that job performance is concerned with quantity and quality produced after a task is accomplished by an individual employee or group of employees. According to Borman and Motowidlo (1993) "job performance is the aggregated financial or non-financial added value by the employees in contribution to the fulfillment both directly and indirectly to the targeted goals of the organization". According to Rivai and Jauvani (2009) "work performance as the real behavior express by everyone as work achievement produced by employee appropriate to their role in the organization". Based on several definitions we can come to conclusion that performance is the results of effort made by employees at workplace within a specified time period. 


\section{Review of literature}

The arrival of new technology brought a large number of amendments in banking organization and structure. The ultramodern transformations left their effect on working atmosphere or conditions and day to day contemporary lives of employees working in the banking sector. The major organizational changes took place in the banking sector as a result of global economic crisis that reel employees under stress, tension and anxiety. A series of big changes took place in financial sector as a result of deregulated and markets globalization of economy affect the working lives of bank employees (Kaur et al., 2017; Hassard et al., 2017). Several studies conducted on banking sector employees using different parameters of stress and revealed that job stress, occupational stress and workplace stress have reported serious issues to the banking sector on employees and put negative effect on employees' health, motivation, adjustment and performance (Petarli et al., 2015; Snorradottir et al., 2013; Silva \& Navarro, 2012). Gender was also found important factor of stress (Li et al., 2015; Amigo et al., 2014).

Fernandes et al. (2012) observed female employees experienced significantly higher degree of stress than males due to increasing demands at workplace and family pressure. Preshita and Pramod (2014) explained that male and female employees working in public and private sector bank employees experienced stress differently on role stagnation, role erosion and role stagnation contributed to occupational stress in India whereas, Kan and Yu (2016), Valente et al. (2015) did not observe significant gender difference. The association amidst job stress and performance discussed in the way that when there are no challenges and no stress; the performance tends to be decrease. Hence optimum level of stress requires increasing the performance. But as stress increases significantly, we may expect a decrease on the performance (Singh, 2001), Wani (2013) observed that output of bank employees and overall output of the firm were affected by motivation and level of job stress. Jayasinghe and Mendis (2017) stated negative association between job stress and performance which also affected the performance of bank employee. Similarly, Priya and Soni (2017) attempted to explore the relationships between job stress and performance and concluded that performance was affected by job stress whereas Vijayan (2018) described that job stressors affect the performance of the employees in a negative way.

\section{Objectives}

The present research aims to study the effect of job stress and need deficiency on performance among bank employees. The objectives are:

1. To explore the relationships between the various facets of job stress and performance of bank employees,

2. To explore the predictors of performance within job stress and need deficiency among bank employees,

3. To explore the predictors of performance within job stress and need deficiency among managerial staff of bank,

4. and to explore the predictors of performance within job stress and need deficiency among non-managerial staff of bank.

\subsection{Hypothesis}

In order to verify the results certain null hypothesis were formulated as follow:

$\mathrm{H} 0_{1}$. There is not any significant relationship between job stressors, need deficiencies and performance of bank employees.

$\mathrm{HO}_{2}$. There are not any predictors within job stressors and need deficiencies of performance among managerial staff of bank.

$\mathrm{HO}_{3}$. There are not any predictors within job stressors and need deficiencies of performance among nonmanagerial staff of bank. 


\subsection{Methodology}

\subsubsection{Sample}

Sample is considered as any small number of individuals, events or objects selected to represent the universe/population according to certain rules. A good sample is unbiased and representative of the whole population. Since, sample is the selection of small group of individuals, objects or events from a population, the sample size is the most important aspects for empirical researches that play an important role in statistical analysis and in drawing conclusion from the obtained results. Keeping in view the objectives of present study, convenient random sampling technique is used in selection of respondents from different public sector banks serving in small cities in UP. The sample of this study consists of 335 Public Sector Bank employees and 135 Managerial Staff and 180 Non-Managerial Staff were selected randomly. Thus, the sample of the present study included male (220) and female (115). The average age of employees was 42 year with an average work experience of 17 years. During data collection respondents were assured that their information will only be used for academic purpose and their identities would not be revealed without any higher authority.

\subsubsection{Tools Used}

Job Stress Measure: Occupational Stress Index was used to measure the job stress developed and was standardized by Srivastava and Singh (1981). The scale comprises of 46 statements, out of 46 items 18 were 'false keyed' and 28 were 'true keyed'. Each item was rated on five-point rating scale with a weighted score of "1" to "5". This scale comprises 12 components but researchers used Role Overload, Unreasonable Group and Political pressures, Responsibilities for People, Poor-Peer Relations, Intrinsic Impoverishment and Strenuous Working conditions as stressors in this study. The reliability and validity of the test were statistically established significant.

Need Deficiency Measure: Need Deficiency scale developed by Porter (1962) was used. The scale consists fifteen items and each item was rated on a 5-point rating scale with a weighted score of " 1 " to "5". The higher score represents satisfaction and the lower scores refer to need deficiency. There are five dimensions we used: Esteem need, Autonomy need and Self-actualization need. The scale has been widely used as it is reported to be highly reliable and valid.

Performance Measure: Performance Scale developed by Sadaqat (2014) was used to measure the performance of bank employees. The scale comprises of five items and each item was rated on a five point rating scale with a weighted score of one to five. The reliability and validity of test were statistically established.

\subsubsection{Design of the study}

In the present study correlational research design has been used to investigate the relationship with each variable and also predict the factors that contribute to influence the criterion variables.

\section{Data Analysis}

Stepwise Multiple Regression Analysis was applied to verify the hypotheses based on the formulated objectives. With the help of SPSS package product, moment correlation and step wise multiple regression analysis were executed to get the authentic scientific results. Table 1 represents overall picture of variables studied on bank employees. All dimensions of stress and need deficiency showed the mean and standard deviation as well as the correlation with performance of bank employees. The role overload is the most dominant stressor with mean value 21.07 and has shown significant positive correlation $(\mathrm{r}=.241$ $\mathrm{P}<.01)$ with performance whereas intrinsic impoverishment with mean 15.82 appeared significant contributor of performance with a significantly higher correlation $(\mathrm{r}=.383, \mathrm{P}<.01)$ followed by unreasonable group and political pressure with mean value 18.00 and $(\mathrm{r}=.117, \mathrm{P}<.05)$ represents a positive correlation 
with performance. Overall, job stress revealed significant positive correlation with performance of employees $(\mathrm{r}=.337, \mathrm{P}<.01)$. Poor peer relation appeared the least dominant stressor in this study and has indicated negative correlation with performance $(\mathrm{r}=-.046)$ preceded by responsibilities for person with mean score of 7.38 and negative correlation with performance $(\mathrm{r}=-.043)$. Esteem need with mean value of 9.77 is one of the dimensions of need deficiency which is inversely correlated with performance of bank employees $(r=-.160, \mathrm{P}<.01)$ whereas self- actualization need appeared the least dominant need among bank employees.

\section{Table 1}

The results of Mean, SD and Correlations of Job Stress, Need Deficiency and Performance among total sample of Bank Employees ( $\mathrm{N}=335)$

\begin{tabular}{llll}
\hline & Mean & Std. Deviation & Correlation with \\
\hline Performance & 16.14 & 5.734 & $.241^{* *}$ \\
Role Overload & 21.07 & 5.457 & $.117 *$ \\
Unreasonable pressures & 18.00 & 5.513 & -.043 \\
Responsibilities for persons & 7.38 & 3.260 & -.046 \\
Poor-Peer Relations & 7.08 & 3.231 & $.383 * *$ \\
Intrinsic Impoverishment & 15.82 & 8.698 & -.046 \\
Strenuous Working Condition & 10.52 & 4.040 & $.337 * *$ \\
Total Job Stress & 79.88 & 14.331 & $-.160 * *$ \\
Esteem need & 9.77 & 4.958 & -.054 \\
Autonomy need & 7.77 & 3.642 & .071 \\
Self-actualization need & 3.12 & 1.516 & $-.109 *$ \\
\hline Total-Motivation & 20.66 & 8.054 & \\
** Significant at .01 level & & & \\
Significant at .05 level & & &
\end{tabular}

\section{Table 2}

Model summary of Regression Analysis on Performance among total sample of Bank Employees $(\mathrm{N}=335)$

\begin{tabular}{|c|c|c|c|c|c|}
\hline Model & $\mathrm{R}$ & R Square & Adjusted R & R Square Change & F Change \\
\hline 1. Intrinsic Impoverishment & $.383 a$ & .147 & .144 & .147 & $57.414^{* *}$ \\
\hline 2 .Intrinsic Impoverishment, Role Overload & $.424 b$ & .180 & .175 & .033 & $13.205^{* *}$ \\
\hline 3. Intrinsic Impoverishment, Role Overload, Esteem need & $.436 \mathrm{c}$ & .190 & .183 & .010 & $4.264^{*}$ \\
\hline 4. Intrinsic Impoverishment, Role Overload, Esteem need, Autonomy need & $.462 \mathrm{~d}$ & .214 & .204 & .023 & $9.810^{* *}$ \\
\hline
\end{tabular}

Table 2 shows the model summary of Multiple Regression analysis and has revealed the predictors of performance from stressors and need deficiencies for bank employees. In the first step, intrinsic impoverishment appeared the most dominant stressor of performance as correlation coefficient between intrinsic impoverishment and performance $(\mathrm{R}=.383)$ depicted that performance of employees was inclined by this component. The acquired value of $\mathrm{R}^{2}=.147$ is the share of disparity in the performance. It explained $14.7 \%$ deviation and $\mathrm{F}$-change $(\mathrm{F}=57.141, \mathrm{P}<.01)$ in the performance of total bank employees. The significant level of $\mathrm{F}$ Change rejects the null hypothesis that intrinsic impoverishment could affect the performance of employees. Role overload appeared another dominant predictor of performance among employees. The correlation coefficient between role overload along with intrinsic impoverishment and performance $(\mathrm{R}=.424)$ has shown linear relationship. The coefficient of determination $\left(\mathrm{R}^{2}=.180\right)$ explained $18 \%$ variation in the performance and the value of $\mathrm{F}$ change $(\mathrm{F}=13.205, \mathrm{P}<.01)$ has found to be significant. The R squared change (.033) produced by role overload along with intrinsic impoverishment, hence it is a good predictor of the performance. In the step third, esteem need as one of the dimensions of need deficiencies of employees has emerged as the most important predictor of performance along with intrinsic impoverishment and role overload stressors. The value of $\mathrm{R}=.436$ has shown some linear relationship between esteem need along with intrinsic impoverishment and role overload and performance of bank employees. The observed value of $\mathrm{R}^{2}=.190$ is the proportion of variation in the performance produced by esteem need along with intrinsic impoverishment and role overload. But alone esteem need produced $4.3 \%$ variation in the performance. Esteem need is the important predictor of the performance as $\mathrm{F}=4.264$ has been observed significant at .01 level of significance. In the fourth step of regression 
model, need for autonomy has appeared as an important predictor of performance along with intrinsic impoverishment, role overload and esteem need of bank employees. It appeared as one of the need deficiencies of employees that influence the performance and revealed correlation coefficient between intrinsic impoverishment, role overload, esteem need and performance $(\mathrm{R}=.462)$ represented that performance of employees was influenced by the need deficiency. The obtained value of coefficient of determination $\left(\mathrm{R}^{2}=.214\right)$, which is accounted for $21.4 \%$ deviation explained in the performance. Autonomy need alone explained $2.4 \%$ variation in the dependent variable. The value of $F$-change $(F=9.81)$ was found significant at .01 level asserted that autonomy need influence the performance of bank employees.

Table 3

Coefficient of Regression on Performance among total sample of Bank Employees $(\mathrm{N}=335)$

\begin{tabular}{|c|c|c|c|c|c|}
\hline \multicolumn{2}{|c|}{ Model } & \multicolumn{2}{|c|}{ Unstandardized Coefficients } & \multirow{2}{*}{$\frac{\text { Standardized Coefficients }}{\text { Beta }}$} & \multirow[t]{2}{*}{$-\mathrm{t}$} \\
\hline & & $\mathrm{B}$ & Std. Error & & \\
\hline \multirow[t]{2}{*}{1} & (Constant) & 12.143 & .602 & & 20.165 \\
\hline & Intrinsic Impoverishment & .253 & .033 & .383 & $7.577 * *$ \\
\hline \multirow[t]{3}{*}{2} & (Constant) & 8.402 & 1.187 & & 7.075 \\
\hline & Intrinsic Impoverishment & .233 & .033 & .353 & $7.013 * *$ \\
\hline & Role Overload & .192 & .053 & .183 & $3.634 * *$ \\
\hline \multirow[t]{4}{*}{3} & (Constant) & 10.286 & 1.493 & & 6.889 \\
\hline & Intrinsic Impoverishment & .235 & .033 & .356 & $7.100 * *$ \\
\hline & Role Overload & .159 & .055 & .151 & $2.883 * *$ \\
\hline & Esteem need & -.124 & .060 & -.107 & $-2.065^{*}$ \\
\hline \multirow[t]{5}{*}{4} & (Constant) & 8.290 & 1.605 & & $5.164 * *$ \\
\hline & Intrinsic Impoverishment & .267 & .034 & .404 & $7.799 * *$ \\
\hline & Role Overload & .168 & .054 & .159 & $3.075 * *$ \\
\hline & Esteem need & -.216 & .066 & -.187 & $-3.274 * *$ \\
\hline & Autonomy need & .286 & .091 & .181 & $3.132 * *$ \\
\hline
\end{tabular}

Table 3 shows the coefficients of the regression for performance of bank employees. In the first step, performance made constant at $\mathrm{B}=12.143$, unstandardized $\mathrm{B}=.25$, standard error .033 found for intrinsic impoverishment with performance in regression equation. Intrinsic impoverishment has emerged as predictor of performance of employees. Standard errors have indicated the variations in sample scores on performance. The Beta coefficient for the independent variable was found .383 which expressed all variables in standardized (z-score) form and t-value was used to test the null hypothesis $\left(\mathrm{H} 0_{1}\right)$ that there is no linear relationship between intrinsic impoverishment and performance. The $t=7.577$ was found significant at .01 level and rejected the null hypothesis.

In the second step, performance made constant at $\mathrm{B}=8.402$, intrinsic impoverishment $=.233$ and role overload $=.192$ with standard errors of $1.187, .033$ and .053 , respectively used to compute regression equation of employees on performance. The Beta coefficients were found as .353 and .183 which explained the variables in the same unit of measurement. The $t$-value of intrinsic impoverishment $(\mathrm{t}=7.013$, $\mathrm{P}<.01)$ and role overload $(\mathrm{t}=3.634, \mathrm{P}<.01)$ were found statistically significant. Furthermore Beta coefficients were found .356 .151 and -.107 that explained the variables in the same unit of measurement. The $\mathrm{t}$-value of intrinsic impoverishment $(\mathrm{t}=7.10, \mathrm{P}<.01)$, role overload $(\mathrm{t}=2.833, \mathrm{P}<.01)$ and esteem need $(\mathrm{t}=-2.065, \mathrm{P}<.01)$ were found statistically significant. In the last step, all variables were used to compute the regression equation of employees on performance. The Beta coefficients were found as .356.151 and -.107 and explained the variables in the same unit of measurement. The low performance among employees attributed to autonomy need not reasonably be satisfied. The t-ration on need for autonomy $(\mathrm{t}=$ 3.132) found significant at .01 level. 
Table 4

Model summary of Regression Analysis on Performance of Managerial Staff of Bank ( $\mathrm{N}=135)$

\begin{tabular}{|c|c|c|c|c|c|}
\hline \multirow[t]{2}{*}{ Model } & \multirow[t]{2}{*}{$\mathrm{R}$} & \multirow[t]{2}{*}{ R Square } & \multirow{2}{*}{$\begin{array}{l}\text { Adjusted } \\
\text { R Square }\end{array}$} & \multicolumn{2}{|c|}{ Change Statistics } \\
\hline & & & & R Square Change & F Change \\
\hline 1. Esteem need & $.362 \mathrm{a}$ & .131 & .124 & .131 & $20.028 * *$ \\
\hline 2. Esteem need, Intrinsic Impoverishment & $.442 \mathrm{~b}$ & .195 & .183 & .064 & $10.545^{* *}$ \\
\hline 3. Esteem need, Intrinsic Impoverishment, Strenuous Working Conditions & $.493 c$ & .243 & .226 & .048 & $8.283^{*}$ \\
\hline 4. Esteem need, Intrinsic Impoverishment, Strenuous W Cond, Poor-Peer Relations & $.522 \mathrm{~d}$ & .272 & .250 & .029 & $5.251^{*}$ \\
\hline
\end{tabular}

Table 4 shows the summary of the model for multiple regression analysis and produced the predictors of the performance from job stressors and need deficiencies for managerial staff. In model-1, esteem need has appeared as important predictor of performance. The correlation coefficient between esteem need deficiency and performance $(\mathrm{R}=.362)$ has shown that performance was influenced by this aspect. The obtained value of $\mathrm{R}^{2}=.131$ represents the variation in performance. It explained $13.1 \%$ variation in the performance managerial staff of bank. The $\mathrm{F}$ Change $(\mathrm{F}=20.028)$ was found significant at .01 level of significance, hence null hypothesis $\left(\mathrm{H}_{2}\right)$ was rejected. Secondly, coefficient of correlation between intrinsic impoverishment along with esteem need and performance $(\mathrm{R}=.442)$ has indicated significant relationship. The $\mathrm{R}^{2}=.195$ explained $19.5 \%$ variation in the performance and alone intrinsic impoverishment was accounted for $6.4 \%$ variation in dependent variable. Further, the value of $\mathrm{R}=.493$ has indicated a linear relationship between strenuous working condition along with esteem need, intrinsic impoverishment and performance. The perceived value of $\mathrm{R}^{2}=.243$ is the proportion of variation in the performance produced by strenuous working condition along with intrinsic impoverishment and esteem need of employees. However, strenuous working condition produced $4.8 \%$ variation in the performance. The poor -peer relationship of managerial staff with employees compel them to perform well. Though, it appeared one of the job stressors for managerial staff that influence the performance. The observed $\mathrm{R}^{2}=.272$ explained $27.2 \%$ variation in performance of managerial staff. It alone explained $2.9 \%$ variation in the dependent variable.

Table 5

Coefficient of Regression on Performance of Managerial Staff of Bank ( $\mathrm{N}=135)$

\begin{tabular}{|c|c|c|c|c|c|}
\hline \multicolumn{2}{|c|}{ Model } & \multicolumn{2}{|c|}{ Unstandardized Coefficients } & \multirow{2}{*}{$\frac{\text { Standardized Coefficients }}{\text { Beta }}$} & \multirow[t]{2}{*}{$\mathrm{t}$} \\
\hline & & B & Std. Error & & \\
\hline \multirow[t]{2}{*}{1} & (Constant) & 16.178 & .744 & & 21.738 \\
\hline & Esteem need & -.285 & .064 & -.362 & $-4.475 * *$ \\
\hline \multirow[t]{3}{*}{2} & (Constant) & 18.790 & 1.079 & & 17.415 \\
\hline & Esteem need & -.278 & .062 & -.353 & $-4.518 * *$ \\
\hline & Intrinsic Impoverishment & -.373 & .115 & -.254 & $-3.247 * *$ \\
\hline \multirow[t]{4}{*}{3} & (Constant) & 15.848 & 1.466 & & 10.811 \\
\hline & Esteem need & -.270 & .060 & -.342 & $-4.491 * *$ \\
\hline & Intrinsic Impoverishment & -.388 & .112 & -.264 & $-3.462 * *$ \\
\hline & Strenuous Working Conditions & .236 & .082 & .219 & $2.878^{* *}$ \\
\hline \multirow[t]{5}{*}{4} & (Constant) & 16.907 & 1.515 & & 11.161 \\
\hline & Esteem need & -.242 & .060 & -.307 & $-4.020 * *$ \\
\hline & Intrinsic Impoverishment & -.358 & .111 & -.243 & $-3.224 * *$ \\
\hline & Strenuous W Cond & .263 & .082 & .244 & $3.219 * *$ \\
\hline & Poor-Peer Relations & -.244 & .106 & -.178 & $-2.292 *$ \\
\hline
\end{tabular}

** Significant at .01 level

*Significant at .05 level

The results shown in Table 5 reveal coefficient of regression on performance of managerial staff. In the first step, esteem need deficiency emerge as predictor of performance shows inverse relationship and Standard errors represent the variations in sample scores on performance. The Beta coefficient for independent variable was found -.362 and suggested that all variables were in standardized (z-score) form and t-value was used to test the null hypothesis, which indicate that there was no linear relationship 
between esteem need deficiency and performance. The $t=-4.475$ found significant beyond .01 level. Secondly, Beta coefficients for esteem need deficiency and intrinsic impoverishment found as -.353 and -.254 described all variables in standardized (z-score) form and t- ratios of - 4.518 and -3.247 , respectively found statistically significant beyond .01 level used to test the null hypothesis. Thus, there is no linear relationship between esteem need deficiency and intrinsic impoverishment with performance among managerial staff. Further, strenuous working conditions have shown positive relationship with performance. The standardized coefficients of Beta for esteem need deficiency, intrinsic impoverishment and strenuous working conditions were found -.342, -.264 and .219 respectively. There is no linear relationship between esteem need deficiency and intrinsic impoverishment with performance whereas strenuous working conditions suggested linear relationship. Lastly, poor-peer relationship found negative in regression equation.

Table 6

Model summary of Regression Analysis on Performance among Non-Managerial Bank Employees $(\mathrm{N}=180)$

\begin{tabular}{|c|c|c|c|c|c|}
\hline \multirow[b]{2}{*}{ Model } & \multirow[b]{2}{*}{$\mathrm{R}$} & \multirow{2}{*}{$\begin{array}{c}\mathrm{R} \\
\text { Square }\end{array}$} & \multirow{2}{*}{$\begin{array}{c}\text { Adjusted R } \\
\text { Square }\end{array}$} & \multicolumn{2}{|c|}{ Change Statistics } \\
\hline & & & & R Square Change & F Change \\
\hline 1. Intrinsic Impoverishment & $.371 \mathrm{a}$ & .137 & .132 & .137 & $28.338 * *$ \\
\hline 2. Intrinsic Impoverishment, Role Overload & $.416 b$ & .173 & .164 & .036 & $7.721 * *$ \\
\hline 3. Intrinsic Impoverishment, Role Overload, Strenuous Working Condition & $.441 \mathrm{c}$ & .194 & .181 & .021 & $4.588^{*}$ \\
\hline
\end{tabular}

** Significant at .01 level

*Significant at .05 level

It is evident from Table 6 that intrinsic impoverishment appeared as the predictor of performance for non-managerial employees of bank. The $\mathrm{R}=.371$ found between intrinsic impoverishment and performance explained the performance of employees influenced by this factor. The observed $\mathrm{R}^{2}=.137$ is the ratio of deviation in the performance explained by this model. It is accounted $13.7 \%$ variation in performance and $\mathrm{F}$-change ( $\mathrm{F}=28.388)$ was found statistically significant at .01 level. Therefore, null hypothesis $\left(\mathrm{HO}_{3}\right)$ was rejected. Result suggested that optimum level of stress positively affect the performance of employees. In the second step, intrinsic impoverishment along with role overload has emerged as the predictor of performance. The correlation coefficient between role overload along with intrinsic impoverishment and performance $(\mathrm{R}=.416)$ was found significant. The observed value of $\mathrm{R}^{2}=.173$ was accounted for $17.3 \%$ variation in the performance, and the role overload was accounted for $3.6 \%$ variation in the dependent variable. The result suggests that job stress emerged as an important factor for the performance. Further strenuous working conditions affect the performance along with intrinsic impoverishment and the role overload. The correlation coefficient between the observed and predicted values of the dependent variable $(\mathrm{R}=.411)$ has shown a linear relationship between strenuous working conditions, role overload and intrinsic impoverishment with performance. The observed value of $\mathrm{R}^{2}=.194$ has been accounted for $1.94 \%$ variation in the performance. Statistically observed value of $F$ change $(F=4.588)$ rejected the null hypothesis.

Table 7

Coefficient of Regression on Performance among Non-Managerial Bank Employees $(\mathrm{N}=180)$

\begin{tabular}{|c|c|c|c|c|c|}
\hline \multirow[b]{2}{*}{ Model } & & \multicolumn{2}{|c|}{ Unstandardized Coefficients } & \multirow{2}{*}{$\begin{array}{c}\text { Standardized } \\
\text { Coefficients }\end{array}$} & \multirow[b]{2}{*}{$\mathrm{t}$} \\
\hline & & $\mathrm{B}$ & Std. Error & & \\
\hline \multirow[t]{2}{*}{$\overline{1}$} & (Constant) & 11.863 & .828 & & $14.326 * *$ \\
\hline & Intrinsic Impoverishment & .252 & .047 & .371 & $5.323 * *$ \\
\hline \multirow[t]{3}{*}{2} & (Constant) & 7.913 & 1.638 & & $4.832 * *$ \\
\hline & Intrinsic Impoverishment & .237 & .047 & .348 & $5.055 * *$ \\
\hline & Role Overload & .204 & .073 & .191 & $2.779 * *$ \\
\hline \multirow[t]{4}{*}{3} & (Constant) & 4.900 & 2.146 & & $2.283^{*}$ \\
\hline & Intrinsic Impoverishment & .286 & .052 & .420 & $5.526 * *$ \\
\hline & Role Overload & .198 & .073 & .186 & $2.729 * *$ \\
\hline & Strenuous W Cond & .230 & .107 & .162 & $2.142 *$ \\
\hline
\end{tabular}

** Significant at .01 level

* Significant at .05 level 
In the first step unstandardized regression coefficient $\mathrm{B}=.252$ with unstandardized standard error .047 for intrinsic impoverishment and constant $\mathrm{B}=11.836$ with standard error .828 have been used to compute regression equation on performance of non-managerial employees (See Table 7). Intrinsic impoverishment as one of the dimensions of job stress has emerged as the predictor of the performance and represents a positive relationship. Standardized Coefficient Beta $=.371$ for independent variable suggested that all variables were in standardized ( $\mathrm{z}$-score) form and $\mathrm{t}=5.323$ has been used to test the null hypothesis which indicates that there was no linear relationship between intrinsic impoverishment and performance. The coefficient is significant beyond .01 levels and suggests that null hypothesis was rejected. Further role overload along with intrinsic impoverishment has shown positive linear relationship with performance. Intrinsic impoverishment along with role overload dimensions of job stress has appeared as the predictors of the performance. Standardized Coefficients Beta $=.191$ and .348 for independent variables have suggested that all variables were in standardized ( $\mathrm{z}$-score) form and $\mathrm{t}=2.779$ and 5.055 respectively found significant at .01 levels and established the linear relationships. Finally unstandardized coefficient of regression for the performance of non-managerial employees of bank made constant $\mathrm{B}=4.90$ with standard error 2.146 . The regression coefficient regression for performance with strenuous working condition was found $\mathrm{B}=.230$ with standard error .107 in regression equation. Intrinsic impoverishment along with role overload and strenuous working conditions has emerged as the predictor of performance. Intrinsic impoverishment, role overload and strenuous working conditions have shown positive relationship with performance. Results have indicated that increased level of job stress up to moderate level increase the performance employees. Standard errors have shown the variations in sample scores on performance. The standardized coefficient of Beta $=.162$ for strenuous working conditions has described all variables in z-score form and t- value was found statistically significant at .05 levels and indicated a linear relationship between independent variables and performance among non-managerial bank employees.

\section{Discussion}

The obtained results have presented in the table followed by descriptions. Now researchers have made some efforts to discuss the results with appropriate evidences. The results shown in Table 1 described means, Sds. and correlations between dependent variable performance and independent variable job stress, need deficiency and its facets. There was a significant positive correlation between total job stress, intrinsic impoverishment, role overload and unreasonable pressure with performance of employees. The observed results have indicated moderate level of job stress increased the performance supported Singh's (2001) results that low stress and high stress inversely affect and interfere with the performance of employees while optimum level stress requires to increase the performance (Ziauddin et al. 2010). It was also argued that stress plays significant role to reduce employee's performance all over the globe caused by poor health, work overload (Rehman et al., 2010). Job stress significantly affects the performance and productivity of bank employees and overall productivity of organization (Wani, 2013). Employees experiencing stress as a result of the changes taken place and face difficulty to overcome new challenges due to lack of internal competency and increased work load, attributed to led them experience optimum level of stress and consequently enhanced performance. The employees work hard beyond the duty hours as a result of demonetization and over target of Government policies to open new accounts, sell different types of insurance policies of different companies.

Indeed employees' experience stress due to a series of big changes took place in financial sector as a result of deregulated markets and globalization of economy affect the working lives of bank employees (Kaur et al., 2017; Hassard et al., 2017). On the other hand, employees' personal and social life affected by job stressors might be attributed to responsibilities for people, poor-peer relations and strenuous working conditions that revealed inverse correlation with performance (Valente et al., 2015; Petarli et al., 2015; Snorradottir et al., 2013; Silva \& Navarro, 2012). Further employees' need deficiencies and performance have shown inverse relationship might be attributed to low scores on esteem need, autonomy need, self-actualization need and total- need deficiency. They wish to satisfy their esteem and autonomy 
needs to choose their own method of work but they are bound to perform the duty within specified manner. Autonomy is very important aspect that enhances the performance of employees. Results clearly have indicated that performance of bank employees are affected by job stress they experience at workplace and the facets of need deficiencies. Wani (2013) observed that productivity of bank employees and overall productivity of organization affected by motivation and level of stress as the needs is not reasonably satisfied. Hence their performance expresses as work achievement inversely affected. Finally we come to conclusion that job stress and need deficiency were the serious issues for banking sector employees, as large number of bank scams occurred, potentially put inverse effect on employees and organization.

\section{Conclusion}

The present era referred to stress bursting as a result of all round global changes took place in economic, political, social, environmental, technological domain, etc. definitely reeled every one of us under stress. It influences the work behavior and performance of employees and organizations. In the present research, some efforts have been made to understand the relationship between job stresses, need deficiency and performance of employees working in banking sector in India with special reference to small cities of Uttar Pradesh. In the first instance, it was observed that intrinsic impoverishment, role overload and unreasonable pressure represented moderate level of stress and positively affect the performance. The results are consistent with findings of Singh (2001) and Ziauddin, et al. (2010). It was also tried to explore the relationship between need deficiency and performance of employees and found that lower level of need deficiency negatively influenced the performance of employees. Further, it was tried to explore the relationships between job stress, need deficiency and performance among managerial and non-managerial staff of bank. Multiple regression analysis has revealed the fact that intrinsic impoverishment, role overload, esteem need and need for autonomy have emerged predictors of performance.

\section{Suggestions}

This piece of research does not shut the door for further researches in this direction taking similar parameter for bank employees. On the basis of the results obtained here, it is hereby suggested that bank management provide adequate and appropriate training programs for employees to enhance their intrinsic skills, increase staff to reduce work load, develop supportive organizational climate, improve communication system, provide autonomy and develop good peer relation. It is also suggested that management must maintain adequate physical working conditions. Further, organization must maintain transparent policies regarding transfer, promotion, and leave. It is also suggested that banking organization must establish proper performance appraisal system and employees must make assessment of their work themselves. It is also suggested that banking organization must create stress free environment to improve the performance of employees.

\section{References}

Agarwala, U.K., Malhan, N.K. \& Singh, R. (1979). Some clarification of stress and its application at work. Indian Journal of Industrial Relations, 15(1), 41-50.

Al Kahtani, N. S., Nawab, A. K., \& Allam, Z. (2016). Organizational role stress: An empirical perspective of university teachers of Kingdom of Saudi Arabia. International Journal of Applied Business and Economic Research, 14(9), 336-355.

Ali, N., \& Allam, Z. (2016). Antecedents and outcomes of interpersonal trust and general role stress: The case of Prince Sattam Bin Abdulaziz University employees. International Journal of Economic Research, 13(1), 395-411.

Ali, N. (2017). A theoretical approach to stress and physical health: Causes and management. International Journal of Current Trends in Science and Technology, 7(11), 20395-20407.

Ali, N., Khan, M. S., \& Allam, Z. (2004). A study on job satisfaction among doctors: Effect of locus of control, sex and marital status. PCTE Journal of Business Management, 1(2), 34-36. 
Allam, Z., \& Ali, N. (2007). Job involvement, job anxiety and job burnout: A comparative study of bank employees. Social Sciences International 23(1)35-44.

Allam, Z. (2007). A study of relationship of job anxiety and job burnout with job involvement among bank employees. Management and labor studies, 21(1) 30-38.

Allam, Z. (2013). Job anxiety, organizational commitment and job satisfaction: An empirical assessment of supervisors in the state of Eritrea. International Journal of Development and Management Review, $8(1), 50-62$.

Allam, Z. (2017a). Police job stress: Understanding through review and remedial measures. International Journal of Mechanical engineering and Technology, 8(10), 460-465.

Allam, Z. (2017b). A scientific approach to understand role stress amongst business school teachers. Man in India, 97(10), 183-196.

Allam, Z. (2019). An inquisitive enquiry of work-life balance of employees: Evidences from Kingdom of Saudi Arabia. Management Science Letters, 9(2), 437-444. 339-346.

Allam, Z., \& Harish, K.T. (2010). Influence of sociodemographic factors on job burnout and satisfaction among Eritrean medical workers. Nigerian Journal of Psychiatry, 8(1), 43-47.

Amigo, I., Asensio, E., Menéndez, I., Redondo, S., \& Ledesma, J. A. (2014). Working in direct contact with the public as a predictor of burnout in the banking sector. Psicothema, 26(2), 222-226.

Beehr, T.A. \& Newman, J.F. (1978). Stress, employee health and organizational effectiveness: A factor analysis, Model and literature Review. Personnel, Psychology, 31, 665-697.

Brief, A.P., Schuler, R.J., Van, S., \& Sell, M. (1981). Management job stress. Boston Little Brown.

Cooper, C.L., \& Marshall, J. (1976). Occupational sources of stress: a review of the literature relating to coronary heart disease and mental ill health. Journal of Occupational Psychology, 49, 1128.

Dar, L., Akmal, A., Naseem, M. A., \& din Khan, K. U. (2011). Impact of stress on employees job performance in business sector of Pakistan. Global journal of management and business research, 11(6).

Fernandes, C. F., Mekoth, N., Kumar, S., \& George, B. P. (2012). Organisational role stress and the function of selected organisational practices in reducing it: empirical evidence from the banking service front line in India. International Journal of Behavioural and Healthcare Research, 3(3-4), 258272.

French, R.O., Rodgers, W. \& Cobb, S. (1978). Adjustment as personal environment fit. In G.V. Coelho D.A. Hamburah and J.E. Adams (eds). Coping and Adaptation, New York. Basic Books.

Halloran, J. (1978). Applied Human Relations. An Organizational Approach Prentice Hall of India Pvt. New Delhi, P-93.

Hassard, J., Teoh, K. R., Visockaite, G., Dewe, P., \& Cox, T. (2018). The cost of work-related stress to society: A systematic review. Journal of occupational health psychology, 23(1), 1.

Jayasinghe, C., \& Mendis, M.V.S. (2017). Stress and Job performance: A study on banking sector of Northern region of Sri Lanka. International Journal of Research Publications, 1(1), September.

Kan, D., \& Yu, X. (2016). Occupational stress, work-family conflict and depressive symptoms among Chinese bank employees: The role of psychological capital. International journal of environmental research and public health, 13(1), 134.

Kaur, K., Kaur, P., \& Kumar, P. (2017). Stress, coping mechanisms and its socio-economic impact on organisations-A review. Indian Journal of Economics and Development, 13(2a), 744-751.

Lewin, K. (1935). A dynamic theory of personality. New York McGraw Hill.

Maslow, A.H. (1943). A theory of human motivation. Psychological Review, 50, 370-396.

McGrath, J.E. (1976). Stress and behaviour in organization.In M.D. Dunnette (Ed.) Hand-book of Industrial and Organizational Psychology Chicago: Rand McNally PP. 1351-96.

Borman, W. C., \& Motowidlo, S. M. (1993). Expanding the criterion domain to include elements of contextual performance. Personnel Selection in Organizations; San Francisco: Jossey-Bass, 71.

Pervin, L. A. (1968). Performance and satisfaction as a function of individual-environment fit. Psychological Bulletin, 69(1), 56.

Petarli, G. B., Zandonade, E., Salaroli, L. B., \& Bissoli, N. S. (2015). Assessment of occupational stress and associated factors among bank employees in Vitoria, State of Espírito Santo, Brazil. Ciencia \& saude coletiva, 20(12), 3925-3934. 
Porter, L. (1962). Perceived deficiencies in need fulfillment as a function of job level. journal of Applied Psychology, 46(6), 375-384.

Preshita, N. T., \& Pramod, P. (2014). A comparative study of occupational stress among public and private sector bank employees of india: a research review. IJABER, 12, 831-841.

Priya, B., \& Soni, S. (2017). Impact of job stress on the performance of the bank employees. International Journal of Science, Environment, and Technology, 6(3), 1843 - 1851.

Rehman, S., Khan, M. A., Afzal, H., Akhter, W., \& Ali, I. (2010). Stress in bankers life: Demands-control model as predictors of employees activity participation. African Journal of Business Management, 4(9), 1679-1690.

Rivai, V., \& Jauvani, E. S. (2009). Manajemen Sumber Daya Manusiauntuk Perusahaan. Edisi Kedua. Raja Grafindo Persada. Jakarta.

Sadaqat, A. (2014). A study on knowledge management of white collar employees in Bhilai steel plant. Unpublished Doctoral Thesis, A.M.U. Aligarh.

Schermerhorn, J. R. (1989). Management for productivity (3rd ed). Wiley, New York, N.Y

Schuler, R. S. (1980). Definition and conceptualization of stress in organizations. Organizational behavior and human performance, 25(2), 184-215.

Silva, J. L., \& Navarro, V. L. (2012). Work organization and the health of bank employees. Revista latino-americana de enfermagem, 20(2), 226-234.

Singh, N. (2001). Organisational Behaviour: Concepts, Theory and Practices: Managing People and Organisations in the 21st Century. Deep and Deep Publications.

Snorradóttir, A., Vilhjálmsson, R., Rafnsdóttir, G. L., Tómasson, K. (2013). Financial crisis and collapsed banks: psychological distress and work related factors among surviving employees-a nationwide study. American Journal of Industrial Medicine, 56, 1095-1106.

Srivastava, A.K. and Singh, A.P. (1981).Construction and standardization of an occupational stress index. A pilot study. Indian Journal of Clinical Psychology, 8(2), 133-136.

Valente, M. D. S. D. S., Menezes, P. R., Pastor-Valero, M., \& Lopes, C. D. S. (2015). Depressive symptoms and psychosocial aspects of work in bank employees. Occupational medicine, 66(1), 54-61.

Vijayan, M. (2017). Impact of Job Stress on Employees Job Performance in Aavin, Coimbatore. Journal of Organisation and Human Behaviour, 6(3), 21.

Wani, S.K. (2013). Job stress and its impact on employee motivation: a study of a select commercial bank. International Journal of Business and Management Invention, 2(3), 13-18

Ziauddin, I., Khan, M., Jam, F., \& Hijazi, S. (2010). The impacts of employees' job stress on organizational commitment. European Journal of Social Sciences, 13(4), 617-622.

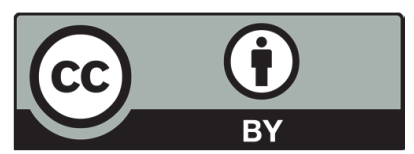

(C) 2019 by the authors; licensee Growing Science, Canada. This is an open access article distributed under the terms and conditions of the Creative Commons Attribution (CCBY) license (http://creativecommons.org/licenses/by/4.0/). 